\title{
THE ELECTRICAL RESEARCH ASSOCIATION
}

$\mathrm{T}$ HE report of the Council of the Electrical Research Association for $1962 *$ opens with a reference to the setting up of an Electronics Dopartmont and to the establishment by the Council of an Electronics Advisory Board. Apart from this important new development the general pattern of the Association's work remains much as in previous years. The Director's report on research work comprises six sections corresponding to the administrative divisions under which the works is organized.

In the field of insulating matorials, a substantial effort is devoted to experimental programmes to furnish data from which British Standard specifications can be drawn up. Typical of these is the completion of work covering the specification of tests for varnished fabrics of cotton, silk, nylon and terylene. Investigations are in progress on fundamontal phonomona of instability loading to break-down, while, in relation to the stable state, it has been shown that conduction in thin films of aluminium oxido in capacitors, in tho prosenco of water vapour, is ionic, and the material is not, as had been supposed, a semiconductor.

In relation to gaseous discharge phenomena measurements of ionization, attachment coofficients and breakdown voltages have been continued for electro-negative gases and data have been obtained for mixtures of molecular gases with sulphur hexafluorido.

The work of the Power Plant Division is devoted mainly to two invostigations, the high-temperature-highpressure properties of steam and the creep behaviour of steels at high temperatures. The facilities of the laboratory for this work have been extended by the addition. of further creep-rupture machines and equipmont for hightemperature tensile testing.

An investigation relating to high-temperature plasmas has been initiated on the low-prossuro high-curront discharge known as the 'D.C.X. Arc'. The mechanism of the dischargo has been studied and it has been demonstrated that very-high-energy lovols can be producod in. the column. It has been found that, by adjusting the heat balance at the cathode, excitation energies up to ten times the normal value can bo produced and stable plasma beams sustained by currents as low as 3 or 4 amp.

Division 3 deals with switchgear, transformers and power system behaviour. Work continues on the synthetic testing of circuit breakers, current zero phenomena, vacuum circuit breaker's and on system severity conditions. Research on transformer steel has been carried out for the Electrical Research Association by the British Iron and Steol Rosearch Association. One of the phenomena under investigation has been that of the anomalous loss - the discrepancy between the moasurod total loss and the sum of the eddy-current and hysteresis losses as traditionally

* The Electrical Research Association. 42nd Annual Report for the year ended 31st Deccmber, 1962. Pp. 101. (Leatherhead: Electrical Research Association, 1963.) calculated. It has now boon shown that the discrepancy disappoars if the eddy current loss is calculated on the basis of the magnetic domain concept except that, for very thin sheets, surface imperfections rostrict domain wall movement. Resoarch is in progress on aluminiumiron alloys and a preliminary investigation has shown that alloys of up to 6 per cent aluminium aro as ductile us 3 per cent silicon-iron.

Division 4 deals with lines and cables for power supply. One part of the work of this division is concerned with the rating of transmission and distribution cables for various conditions of service, another deals with surge phenomena resulting from lightning discharges and with the characteristics of lightning and of thunderstorms. These latter investigations are of particular interest to supply systems in certain tropical areas, and the Electrical Research Association maintains an active collaboration with workors in various parts of the world in the collection of thunderstorm statistics.

The non-industrial applications of Division 5 include the Association's activitios in agriculturo and horticulture which are carried on at the Shinfield Research Station. There is, in addition, a substantial programme doaling with various aspects of electric heating, in particular offpeak floor-heating and associated problems.

Division 6, "Industrial Applications", comprises a rango of topics. Radio interference, a subjoct to which the Association has contributed over a long period, is undergoing national and international co-ordination and standardization. Work on flame-proof enclosures and on intrinsic safety continues. Research on contactors has furnished a theoretical basis for distinguishing the phenomena of metal transfer betwoen coppor contacts in a d.c. are at currents less than $15 \mathrm{amp}$ from the behaviour of contacts at high currents with which bulk melting can occur. This work has also offered an explanation of the formation of poorly conducting layers on contacts.

As has been mentioned, a new Department of Electronies has been established. The initial programme of work for this Department covers fundamental research into the electrical properties of thin conducting and dielectric films. The number of new reports issuod to membors during tho yoar was fifty-nine.

When the Association moved to the then new laboratories at the present site at Leatherhead soven years ago, the Switchgear Department remainod bohind at Perivale for tho time being. This Department is now moving to Leatherhead and will be housed in a new building.

At the end of the report of the Council, referenco is made to the financial position of the Association. Rising costs and expenses associated with new developments have involved the Association in a substantial deficit on the year's working. It has, in the circumstances, been doemed advisable to restrict in certain respects the programme for the current year.

J. Greig

\section{EMPLOYMENT OF UNITED KINGDOM UNIVERSITY GRADUATES}

\begin{abstract}
TNORMATION relating to the employment of the $16,736 \mathrm{mon}$ and 5.338 wom who obtained first degrees in arts and pure and applied scioneo at univorsities in Great Britain in 1961-62 is summarized in a report issued by the University Grants Committo*; it

* University Grants Committee. First Employment of University Graduates, 1061-1062. Yp. 11i+24, (London: H.M.S.O., 1963.) 2s, net.
\end{abstract}

does not include those who graduated in medicine dentistry and votorinary scinneo,

Of the men, 44.5 per cent graduated in arts and social studins, 31.5 por eent in purs scienee, and 24 per cent in applind science; for womnn, the corresponding figures are $71 \cdot 0,27 \cdot 6$ and $1 \cdot 4$ per cent, respectively. Taking men and women together, 44.9 per cent of the graduates in arts 
and social studies undertook further education or training and 38 per cent entered employment; $55 \cdot 7$ per cent of the women undertook further education or training compared with 39.4 per cent of the men. However, while 13.0 per cent of men undertook research or furthor academic study, only 7.0 per cent of the women did so; on the other hand, 34.5 per cent of women undertook teacher training compared with 17.9 per cent of the men.

For pure and applied science, taking men and women together, 36.9 per cent undertook further education or training and 50.9 per cent entered employment; for the men, the corresponding figures are $50 \cdot 3$ per cent and $39 \cdot 3$ per cent in pure science and 17.5 per cent and 66.1 per cent in applied scionce, and for women in pure and applied science, 41.6 per cent and $50 \cdot 2$ per cent. For graduates in both arts and social studies and in pure and applied science, only $2 \cdot 2$ per cont entered employment overseas, but for mon this figure was 2.8 per cent for applied science and 1.9 per cent for pure science. Of science graduates who entered employment within the United Kingdom, 9.3 per cent of the men entered the public service (other than education), 19.7 per cent education (in schools, colleges and universities without postgraduate training first) and 66.3 per cent industry and commeree; for graduates in applied science the corresponding figures are $10.4,2.8$ and 84.9 per cent, respectively; and for women graduates in pure and applied science, $22 \cdot 9,43 \cdot 3$ and $29 \cdot 3$ per cent, respectively. For graduates in arts and social studies, 13.9 per cent of the men entered the public service, 19.9 per cent education, and 46.5 per cent industry and commerce; for women the corresponding figures are $21 \cdot 8,48 \cdot 7$ and $17 \cdot 2$ per cent, respectively.

The report shows that of every 100 men graduating in puro scionee, 31 undertake researeh or further academic study and 14 undertake teacher training; in applied science these figures are 16 and 1 , respectively, and for womon in pure and applied sc'ince 13 and 25 , respectively. Over the past five years, the proportion of graduates in pure and applied science undertaking teacher training has risen slightly from 9 to 11 per cent, and of those undertaking research or further academic study from 22 to 23 per cent, but the proportion gaining employment at home in education or gaining employment overseas has remained unchanged at 7 per cent and 2 per cent, respectively.

\section{SULPHATE EXPANSION IN CONCRETE: A NEW HYPOTHESIS}

T HE phenomenon of sulphate expansion in cement paste or concrete is a well-known hazard to be reckoned with in building and highway construction by civil engineers and others concerned. For example, in highly gypsiferous clays, such as obtain at certain horizons and places in the London Clay, the use of ordinary Portland cement concrete is avoided in favour of sulphateresisting or aluminous coments. The causes of sulphate attack in concrete have received international attention over the years, but even to-day the precise mechanism of the reaction is still an open question.

Sulphate expansion means an increase in volume of cement paste or concrete occurring as a result of chemical reaction between the hydration products of cement and sulphate-bearing solutions with which it may come in contact. T. Thorvaldson has stated (1954): "While the formation of crystals of sulpho-aluminate and gypsum in Portland cement mortar during disintegration in sulphate solutions is well established, many observations throw doubt on the assumption that physical forces of crystallization are the primary cause of expansion and loss in strength". Previous theories have assumed that the chief cause of expansion is the formation of ettringite (3CaO.Al2 $\mathrm{O}_{3} \cdot 3 \mathrm{CaSO}_{4} \cdot 31 \mathrm{H}_{2} \mathrm{O}$ ) (Larsen), from aluminabearing compounds present in cements.

S. Chatterji and J. W. Jeffery have put forward a new theory which suggests that sulphate expansion is caused by solid-state conversion of calcium aluminate hydrate to calcium aluminate monosulphate and "that this expansion may or may not be accommodated depending on the concentration of lime in the liquid phase" (Magazine of Concrete Research, 15, No. 44; July 1963).

S. Chatterji and A. Grudemo have investigated paste hydration of calcium aluminate gypsum mixtures with and without calcium hydroxide (paper in course of publication). "The pastes, of water/cement ratio 0.6 , were contained in brittle plastic vials. In the case of the pastes containing $\mathrm{Ca}(\mathrm{OH})_{2}$, the vials which remained unused after 14 days had cracked by expansion before 3 months, while the three without $\mathrm{Ca}(\mathrm{OH})_{2}$ remained intact. The course of the reaction was followed by $\mathrm{X}$-ray diffraction and electron-optical techniques. It was found that the initial sulphate-bearing compound was ettringite, but the final one was calcium aluminate monosulphate $\left(\mathrm{C}_{3} \mathrm{~A}\right.$. CaSO $\left.\mathrm{Ca}_{4} \cdot x \mathrm{H}_{2} \mathrm{O}\right)$ in both cases; the change from ettringite to monosulphate occurred between 14 days and 3 months, the period during which the vials cracked" (see p. 463 of this issue).

The basis of this hypothesis is briefly explained in Chatterji and Jeffery's paper, but, as they rightly point out, the theory on which their explanations rest is far from being established. If it is confirmed by further work, then the next stage is to establish the mechanism of disruption. The hope is expressed that by putting forward this hypothesis now, further research on this subject will be stimulated.

H. B. MrLner

\section{INTER-INDUSTRIAL OCEANOGRAPHIC RESEARCH IN THE UNITED STATES}

$\mathrm{T}$ HOUGH no exact figures are availablo, it is reasonably certain that since the war, and probably for some years before it, the United States has spent more on oceanographic research than the rest of the Western world put together. The Federal Government alone is spending 124 million dollars per annum at the present time, and plans to treble this over the next ten years. Much of this money is spent on buying or developing equipment, and a number of small firms have sprung up in the past decade to satisfy this requirement. However, the sums involved are now sufficient to interest big business. One Californian oceanographer who was visiting Great Britain last year pointed out that his firm had set up an Oceanographic Systems Group with an initial budget of 1 million dollars, and had told the Group leader that when he had spent this he should ask for more. At the time of the first conference, commercial firms in California alone employed 32 professionally trained oceanographers (mostly physical oceanographers), quite apart from the supporting staff of engineers. For comparison, the whole of Western. Europe can muster about 130 physical oceanographers in all types of employment. 